\title{
Exploring External Validity of Common Pool Resource Experiments: Insights from Artisanal Benthic Fisheries in Chile
}

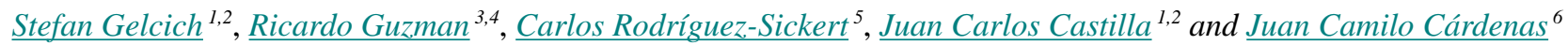

ABSTRACT. We explore the external validity of a common pool resource (CPR) laboratory experiment. The experimental subjects were artisanal fishers who exploit benthic resources on the coast of Chile. A first set of subjects was recruited from fishers' unions that comanage their resources through territorial user right areas. These unions differ in their performance, which is largely the outcome of the cooperative efforts of their members. A second set of subjects was recruited among nonunionized fishers who do not participate in the comanagement system. They fish exclusively in open-access areas and barely cooperate in their fishing. Membership of a union and the union's performance in comanagement were related to the subjects' behavior in the laboratory. In the CPR experiment, members of high-performance unions showed high cooperation with each other, while members of low-performance unions cooperated significantly less. Nonunionized fishers did not cooperate at all. We also explored how the weak external enforcement of an individual quota can trigger changes in behavior, what we refer to as internalizing the norm. Only the members of high-performance unions internalized the norm. They refrained from overfishing until the end of the game, even though the sanction for exceeding the quota was not strong enough to be dissuasive from the point of view of pure self-interest. This study provided insight on the experimental analysis of cooperation in artisanal fisheries and suggested that the capacity to internalize norms is important to the sustainable exploitation of artisanal fisheries common pool resources.

RESUMEN. Exploramos la validez externa de un experimento de laboratorio con un recurso de uso común. Los sujetos del experimento han sido pescadores artesanales que explotan recursos bentónico en la costa de Chile. Un primer grupo de personas proviene de organizaciones de pescadores que utilizan sistemas de co-manejo explotando estos recursos a través de derechos territoriales de uso. Un segundo grupo de pescadores incluidos en este experimento no pertenecían a organizaciones de pescadores y tampoco participaban en sistemas de co-manejo, pescando de forma exclusiva bajo un régimen de acceso abierto y rara vez cooperan entre ellos. Este trabajo realiza un análisis comparativo entre el desempeño en co-manejo entre estas diferentes organizaciones de pescadores y el comportamiento colaborativo de los pescadores. Los resultados indican que los pescadores miembros de organizaciones con elevado desempeño presentan un alto grado de cooperación entre ellos, mientras que aquellos donde se observa bajo desempeño su nivel de cooperación es también significativamente más reducido. El trabajo también demuestra que los pescadores que no forman parte de organizaciones de pescadores tampoco mostraron ningún tipo de cooperación. Asimismo, tamibén investigamos cómo un débil cumplimiento externo de la normativa en relación a las cuotas de capturas puede provocar cambios en el comportamiento de los pescadores, entendido aquí como internalización de las normas. Sólo los miembros de organizaciones con un Elevado desempeño demuestran haber internalizado las normas. Se abstuvieron de continuar sobrepescando hasta el final de juego a pesar de que la sanción prevista por exceder la cuota no era lo suficientemente disuasoria desde la perspectiva de su propio interés. Este estudio aporta nueva luz sobre el análisis experimental de la cooperación en pesquerías artesanales, y sugiere que la capacidad de internalizar las normas es relevante para la explotación sostenible de recursos comunes en pesquerías artesanales.

Key Words: artisanal fisheries; benthic resources; comanagement; common pool resources; internalization of norms; laboratory experiment; small-scale fisheries; territorial user rights

\footnotetext{
${ }^{1}$ Centro de Conservación Marina \& Departamento de Ecología, Facultad de Ciencias Biológicas, Pontificia Universidad Católica de Chile, Chile, ${ }^{2}$ Laboratorio Internacional en Cambio Global, Consejo Superior de Investigaciones Científicas (CSIC) \& Pontificia Universidad Católica de Chile (PUC), España-Chile, ${ }^{3}$ Centro de Investigación en Complejidad Social (CICS), Facultad de Gobierno, Universidad del Desarollo, Santiago, Chile, ${ }^{4}$ Facultad de Economía y Negocios, Universidad del Desarrollo, Santiago, Chile, ${ }^{5}$ Centro de Investigación en Complejidad Social (CICS), Facultad de Gobierno, UDD, Santiago, Chile, ${ }^{6}$ Facultad de Economía, Universidad de los Andes, Bogotá, Colombia
} 


\section{INTRODUCTION}

In artisanal fisheries, top-down management policies and open-access regimes typically lead to overfishing. To address this problem, some researchers and development agencies are now advocating a shift toward comanagement in which the responsibility for the sustainable use of the common pool resource is shared by authorities and artisanal fishing communities (Ostrom 1990, Sen and Nielsen 1996, Gelcich et al. 2009, Cinner et al. 2012). Comanagement aims to reconcile authorities' concern for efficiency and sustainability with the communities' demand for equal opportunities, selfdetermination, and self-control (Fanning 2000). The authorities establish a general legal framework, while the communities regulate the actions of their members and enforce these regulations (Sen and Nielsen 1996, Pomeroy and Berkes 1997).

Despite the increasing success of comanagement fishery systems, results have been mixed, and cases of failure still abound. Critical to the success of comanagement systems is the disposition of fishers to cooperate with their community and refrain from overfishing, even in scenarios of weak enforcement. Unfortunately, the determinants of cooperation among artisanal fishers are not yet fully understood (Cinner et al. 2012, Gelcich et al. 2005a,b, 2009). A better understanding is needed to advance the design, implementation, and continual improvement of comanagement systems.

Our current understanding of cooperation among artisanal fishers in comanagement settings is mainly derived from case studies (Nielsen et al. 2004, Gelcich et al. 2006, Cinner et al. 2012). These studies suggest several determinants of cooperation: for example, the social capital of the community, the presence of graduated sanctions, and the community's dependency on the common pool resource (Ostrom 1990, Gelcich et al. 2007, Cinner et al. 2012). However, it is difficult to conclusively identify the determinants of cooperation by analyzing case studies alone because most case studies lack good counterfactuals (George 2005).

By controlling for confounding variables, laboratory economic experiments can help identify the determinants of cooperation in the field (Ostrom 2006). Common pool resource (CPR) experiments using subjects who share a real natural resource, e.g., an artisanal fishery, have provided valuable insights in particular (Cárdenas 2003, 2004, 2009, 2011 Cárdenas and Ostrom 2004, Rodríguez-Sickert et al. 2008). Because the subjects, e.g. artisanal fishers, "play" a real CPR game in their daily lives, they can help explore and affirm the robustness of findings from field studies (Cárdenas and Ostrom 2004). During a CPR experiment, each subject privately decides how many units of a resource he will extract. Just like in real life, there is a conflict of interest between the individual and his group; the subject may maximize individual profits by extracting as many units as possible, but this reduces the profit of the other group members. The Nash equilibrium of this game is the depletion of the common pool resource, the so-called tragedy of the commons (Hardin 1968). In practice, however, many experimental results contradict the predictions of the Nash equilibrium. Subjects often manage to cooperate in the sustainable exploitation of the common pool resource and avert the tragedy of the commons (Ostrom 1990, 2006, Ostrom et al. 1992).

Field research and case studies can be used to check the correspondence between the subjects' behavior in the laboratory and their actions in the field (Singh 1994, Ostrom 2006). In experimental analysis, this correspondence is known as external validity. Externally valid experimental results can be useful when designing and implementing comanagement policies; therefore, external validity checks are of crucial importance (Levitt and List 2007). To our knowledge, only four studies have investigated the external validity of CPR experiments. Carpenter and Seki (2011) and Fehr and Leibbrandt (2011) found evidence of external validity, whereas Gurven and Winking (2008) and Hill and Gurven (2004) did not.

We present the results of a CPR experiment. The experimental subjects were artisanal fishers who exploit benthic resources on the coast of Chile. The subjects were recruited from two kinds of communities: fishers' unions that comanage their resources through territorial user right areas, and nonunionized fishers restricted to open-access sites. We investigated the external validity of the experiment, relating the subjects' behavior in the laboratory to their home community type as a proxy of cooperation: high-performance fishers' unions, lowperformance fishers' unions, or nonunionized fishers. We also investigated how weak enforcement can trigger the internalization of an antipoaching social norm, and how the subjects' propensity to internalize the norm varies with the degree of cooperativeness of their home communities. The unions in our sample differed in their level of dependency on benthic resources. We took advantage of this variability to explore the effects of dependency on cooperation and the internalization of norms.

\section{METHODS}

\section{Research setting}

We conducted the study in artisanal benthic fisheries located on the coast of Chile. Since 1997, these fisheries have operated under a comanagement regime in which artisanal fishers unions are granted territorial user rights. The territorial user rights allow exclusive access and fishing rights in certain areas of the seabed (Gelcich et al. 2010). These areas are called Management and Exploitation Areas for Benthic Resources (MEABRs). Sen and Nielsen (1996) described a spectrum of comanagement systems ranging from "instructive," in which 
the government establishes channels of dialogue with the communities but ultimately imposes its management decisions, to "informative," in which communities make their own management decisions and inform the government of these decisions. The Chilean comanagement system lies between these two extremes; artisanal fishers' unions have management and enforcement rights over their MEABRs, and the state enforces fishers' compliance with MEABR plans.

To be granted an MEABR, a fishers' union must submit a fiveyear management plan to the Undersecretary of Fisheries that commits the union to yearly assessments and implements a total allowable catch. This plan is developed by the union in conjunction with expert consultants. All resources extracted from the MEABR must be reported to the National Fisheries Service, which oversees compliance with the management plan. The union is responsible for adhering to the plan; to that end, it must monitor its members and enforce its internal norms. The National Fisheries Service enforces MEABR plan compliance and has the authority to sanction poachers (Gelcich et al. 2007).

Because of its historically high economic value, $90 \%$ of existing MEABRs focus on loco (Concholepas concholepas) as their main target species (Castilla and Gelcich 2008). Before the establishment of the comanagement system, access to the loco fishery was open, and the species was overexploited by artisanal fishers (Thorpe et al. 1999). To protect and recover the species, the fishery was closed for four years and then reopened with an individual quotas system. This system was replaced shortly thereafter by the MEABR comanagement system (Schurman 1996, Meltzoff et al. 2002). The loco biomass has recovered within many MEABRs, largely because of the comanagement system (Gelcich et al. 2010).

Currently, there are 707 MEABRs in operation, and some 30,000 fishers are registered as divers or coastal gatherers who exploit benthic resources and algae (Castilla 2010, SUBPESCA 2010). Despite the large financial investment and the government's commitment to the MEABR policy, the performance of fishers' unions has been mixed (Meltzoff et al. 2002, Gelcich et al. 2007, 2008, 2009). Some unions have managed to comply with the regulations and exploit their resources sustainably and profitably. Other unions have failed. Also, some fishers remain nonunionized and are constrained by law to dive in open-access sites, although they often poach within MEABRs, jeopardizing the system. For a detailed account and analysis of the reform of artisanal fisheries in Chile, see Gelcich et al. (2010).

\section{Subjects}

Our subjects were 85 artisanal fishers; 55 were unionized, and 30 were nonunionized. Unionized fishers worked in six MEABRs located on the central coast of Chile: Maitencillo, El Quisco, Matanzas A, Las Cruces, Matanzas B, and La Boca de Rapel. In contrast, nonunionized fishers were restricted by law to dive in open-access sites and did not have permission to harvest loco. As more unions have applied for and extended their MEABRs, open-access sites have become increasingly scarce and less productive. Not surprisingly, many nonunionized fishers harvest loco illegally and poach within MEABRs. The nonunionized fishers who participated in our experiment worked at several sites along the central coast. Figure 1 depicts the geographic location of the fishing sites where the experiment was performed.

Fig. 1. Geographic location of the fishing sites where the experiment was performed.

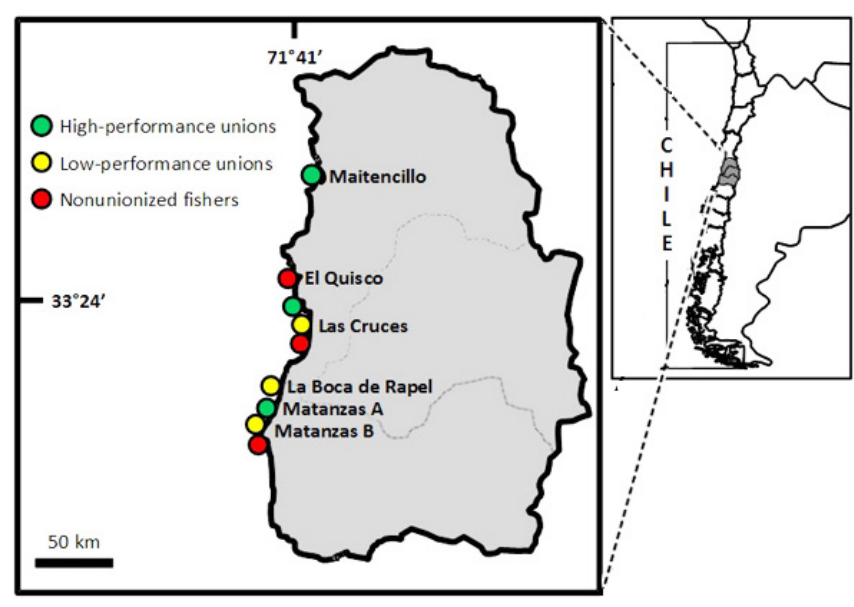

The six fishers' unions in the sample were selected because they exhibited high and low levels of performance (see Table 1). We made a preliminary selection based on previous research experience and on the researchers' direct knowledge of the unions (Gelcich et al. 2009, Marín et al. 2012). To objectify the final selection, we constructed a performance index that corresponded to an average of seven variables. These variables included measures of internal enforcement and compliance with the union norms, assessed by the union president; measures of comanagement performance, assessed by the National Fisheries Service; and measures of ecological performance, evolution of the total allowable catch, and biodiversity. Even though the performance index is not a direct measure of cooperativeness, all variables included in the index were closely related to cooperation among union members. Appendix 1 provides a detailed description of the performance index.

Cooperative behaviors in fishers' communities are expressed through a series of institutions and social practices. In terms of their institutions and social practices, high-performance unions, low-performance unions, and nonunionized fishers can be characterized briefly as follows. 
Table 1. Characteristics of the sampled unions.

\begin{tabular}{|c|c|c|c|c|}
\hline \multirow{2}{*}{$\begin{array}{l}\text { Union } \\
\text { Maitencillo }\end{array}$} & \multirow{2}{*}{$\begin{array}{c}\text { Performance }^{\dagger} \\
\text { High }(0,8)\end{array}$} & \multicolumn{2}{|c|}{$\begin{array}{c}\text { Dependency on } \\
\text { benthic resources }\end{array}$} & \multirow{2}{*}{$\begin{array}{c}\begin{array}{c}\text { Number } \\
\text { of subjects }\end{array} \\
10\end{array}$} \\
\hline & & High & $(75 \%)$ & \\
\hline El Quisco & High $(0,6)$ & Medium & $(23 \%)$ & 10 \\
\hline Matanzas A & High $(0,7)$ & Low & $(3 \%)$ & 10 \\
\hline Las Cruces & Low $(0,11)$ & High & $(74 \%)$ & 10 \\
\hline La Boca de Rapel & Low $(0,19)$ & Medium & $(25 \%)$ & 10 \\
\hline Matanzas B ${ }^{\S}$ & Low $(0,1)$ & Low & $(3 \%)$ & 5 \\
\hline
\end{tabular}

A typical high-performance union has an efficient MEABR committee, which oversees the operation of the MEABR. The committee makes a monthly presentation to the members of the union, covering topics such as harvesting plans, investment plans, and financial management. Compliance with fishing quotas is also addressed during the presentation. To enforce its locally agreed-upon set of norms, a typical highperformance union has an effective system of internal sanctions. These sanctions are graduated, and repeat offenders can be expelled from the union. Norm compliance is high, and the members of the union have a favorable attitude toward compliance. As a result of its well-functioning institutions and practices, the union fully complies with the legal requirements to have an MEABR. Furthermore, the union's total allowable catch has remained constant or has increased over the past five years.

A typical low-performance union does not have a permanent MEABR committee. This type of union has few formal institutions to regulate the operation of its MEABR. Although internal sanctions exist, they are not enforced by the union members. The fishers have developed storylines that vindicate overharvesting loco, and this activity is not frowned upon (see Gelcich et al. 2005a for a detailed analysis of the fishers' discourses). As a result of its deficient institutions and practices, a typical low-performance union barely complies with the legal requirements to have an MEABR. Furthermore, the union's total allowable catch has remained constant or decreased in the last five years.

Nonunionized fishers understand the advantages of the comanagement system. However, they have opted not to participate for several reasons; they want to fish without restrictions, they are unwilling to incur the costs of operating an MEABR, or they are simply unable to organize and form a union (Gelcich et al. 2005a,b). Nonunionized fishers frequently sneak into MEABRs to poach. Poaching is justified through narratives in which the MEABRs are presented as a fraud created by unions who have usurped historical rights over the marine resources, which were once open to all registered fishers, (Gelcich et al. 2005a). Nonunionized fishers typically dive alone or in pairs. They sell their catch to local restaurants and in other informal markets.

Besides having different levels of performance, the six fishers' unions included in the sample differed in their level of dependency on benthic resources. Dependency was measured as the percentage of total landings that these resources represented in metric tons (see Table 1).

\section{Experimental procedure}

We conducted 18 experimental sessions between March and May 2012. In each session, the subjects were assembled in groups of five to play a CPR game. This game simulated the joint exploitation of a common pool resource, an activity that the subjects often performed in their daily lives. The CPR game was programmed in $\mathrm{z}$-Tree and implemented in the field using a network of portable computers (Fischbacher 2007). To facilitate the use of the computers, each keyboard was covered with cardboard with a cutout that exposed only the numeric keypad.

At the beginning of each session, the session monitor explained the game to the players and taught them how to use the experimental software (the instructions are reproduced in Appendix 2). The monitor then gave them a quiz to ascertain their understanding of the game. All subjects passed this quiz. The subjects' quickness to understand the game can be explained in part by their daily life experiences. Fishers regularly participate in market transactions, and market transactions require mastery of basic arithmetic operations and a minimal understanding of economic incentives. The game was also easy to understand because it was presented in very concrete terms using the jargon of the CPR problem that the subjects faced in real life. After the quiz, the subjects played five trial rounds to clarify any remaining doubts. The experiment began after these trials.

Each experimental group consisted of five members of the same fishing community. To minimize the effects of thirdparty observation on the subjects' behavior, we used a double- 
anonymous experimental design (Bardsley et al. 2010). This means that anonymity was maintained between the players and also between the players and researchers. Anonymity reduced the possibility of side payments between the subjects.

We took additional steps to mitigate the effects of peer pressure. The group members were chosen at random from a list of union members. Relatives and coworkers were assigned to different groups, and union presidents were excluded from the experiment. No communication among the group members was allowed. The subjects were paid in cash after the game, and payments to each subject were made in private.

Subjects could participate in only one session. Communication between outgoing and incoming groups was also prevented, so the subjects had no knowledge of the game rules before playing. This reduced the possibility of prior coordination between members of a group and side payments.

Game payoffs were adjusted so that subjects' total profits approximated an average day's income. The subjects earned between CLP\$10000 (US\$20) and CLP\$20000 (US\$40).

\section{The common pool resource experiment}

In our version of the CPR game, five subjects played the role of divers who harvest loco in a common fishery. The game lasted for 20 rounds. At the beginning of every round, each subject was endowed with 100 units of loco, which represented his individual quota. Then each subject had to privately decide if he would overharvest and how many additional units he would overharvest. He could overharvest from 0 to 50 additional units.

Each subject faced a trade-off between his individual interest and the interest of his group. For each additional unit that he overharvested, each of the other members of his group lost half a unit. For example, if a subject overharvested the maximum of 50 loco, the rest of the players lost 25 loco each. This feature of the game mimicked a real externality. In actual loco fisheries, a diver who exceeds his quota increases his own profits while contributing to a reduction of the population of loco. Consequently, the other divers must incur higher searching costs, and their harvests are subsequently reduced. After every round, each subject was informed about the average harvest of his group, his losses due to the negative externality, and the profit he obtained in that round. Subjects were not made aware of the individual decisions of others in the group.

Formally, the rules of the game can be expressed as follows. The subjects are indexed by $i \in S$, where $S=\{1,2,3,4,5\}$, and the rounds of play are indexed by $t=1,2, \ldots, 20$. The monetary payoff of subject in round $t$ is given by the following equation:

$$
v_{i t}=\$ 10 \times\left(100+x_{i t}-\frac{1}{2} \sum_{j \in S_{-i}} x_{j t}\right)
$$

where $x_{i t} \in\{0,1, \ldots 50\}$ is subject $i$ 's overharvest in round $t, S$ ${ }_{i}$ is the set of the four other members of his group, and $\$ 10$ (10 Chilean pesos) is the unitary value of loco. Because subject $i$ has been endowed with 100 units, his total harvest would be $100+x_{i t}$

The first 10 rounds of the game represent the baseline treatment of the experiment, which is characterized as a de facto openaccess regime. In this treatment a quota of 100 locos exists, but it is not enforced. Hence, during the first 10 rounds, subject $i$ 's expected payoff is represented by the following equation:

$$
v_{i t}=\$ 10 \times\left(100+x_{i t}-\frac{1}{2} \mathrm{E} \sum_{j \in S_{-i}} x_{j t}\right),
$$

for all $t=1, \ldots, 10$.

Without enforcement, a rational, selfish, and risk-neutral subject will maximize his expected payoff by overharvesting as many units as possible: 50 per round. The other four members of his group will do the same, so the group's total overharvest will be 250 units per round, the maximum possible number. Each subject will lose 100 units because of the other subjects' overharvest. His final harvest will be 50 , which is equal to his quota plus his overharvest minus his loss from the negative externality. As a result, each subject will earn $\$ 500$ per round, the minimum possible payoff. A tragedy of the commons is the unique equilibrium during the first 10 rounds of play.

At the start of round 11, the rules of the game change unexpectedly and permanently. The open-access regime is replaced by a regulated regime. After each of the remaining rounds, the computer "inspects" two subjects selected with a random number generator. If the computer finds that a subject has exceeded his quota, it "confiscates" the subject's entire harvest of that round. Therefore, subject $i$ 's expected payoff in round $t$ is given by the following expression:

$$
\begin{aligned}
& E \pi_{i t}= \\
& \left\{\begin{array}{r}
\$ 10 \times\left(100+x_{i t}-\frac{1}{2} \mathrm{E} \sum_{j \in S_{-i}} x_{j t}\right), \\
\quad \text { if } x_{i t}=0 \text { or } t \leq 10, \\
\frac{3}{5} \times \$ 10 \times\left(100+x_{i t}-\frac{1}{2} \mathrm{E} \sum_{j \in S_{-i}} x_{j t}\right),
\end{array}\right.
\end{aligned}
$$


From the above expression, it follows that subject $i$ will be deterred from overharvesting in round $t$ if and only if the following expression is true:

$$
\begin{aligned}
& \frac{3}{5} \times \$ 10 \times\left(150-\frac{1}{2} \mathrm{E} \sum_{j \in S_{-i}} x_{j t}\right) \\
& \leq \$ 10 \times\left(100-\frac{1}{2} \mathrm{E} \sum_{j \in S_{-i}} x_{j t}\right) .
\end{aligned}
$$

This condition can be simplified as follows:

$$
\mathrm{E} \sum_{j \in S_{-i}} x_{j t} \leq 50,
$$

meaning that the subject will be deterred if and only if he expects that the rest of his group will overharvest 50 or less units in total. This leads to two alternative equilibria, which we describe below.

If condition (5) is met, all subjects will refrain from overharvesting, so the group's total overharvest will be 0 units. As a result, each subject will earn $\$ 1000$ per round, the maximum possible amount. We call this outcome of the game the "cooperative equilibrium", because in this equilibrium the subjects cooperate in the sustainable exploitation of the resource. In the cooperative equilibrium, everyone cooperates because they trust that the others will cooperate, too.

If condition (5) is not met, all subjects will overharvest 50 units per round, so the group's total overharvest will be 250 units. As a result, each subject will earn $\$ 500$ per round, the minimum possible amount. We call this outcome of the game the "noncooperative equilibrium", because in this equilibrium the subjects do not cooperate in the sustainable exploitation of the resource. In the noncooperative equilibrium, no one cooperates because nobody trusts that the others will cooperate too.

The cooperative equilibrium is unstable, whereas the uncooperative equilibrium is stable. To grasp the intuition behind this statement, consider the simple case in which subjects update their beliefs based on the previous behavior of the rest of their group. Specifically, suppose the following:

$$
\mathrm{E} \sum_{j \in S_{-i}} x_{j t}=\sum_{j \in S_{-i}} x_{j t-1 .}
$$

If the right side of this equation is between 0 and 50, subject $i$ will overharvest 0 units in round $t$. Otherwise, he will harvest 50 units. Suppose further that for a certain period of time, the game has remained in its cooperative equilibrium. Subjects, of course, are imperfect. They may deviate from their equilibrium strategies and play suboptimally. For example, they may increase their overharvest from 0 to 13 units each.
As a result, the right side of equation (6) rises from 0 to 52 for all subjects. Based upon equation (5), a subject's optimal response will be to overharvest 50 units each in the next round. Therefore, small levels of poaching in the game are enough to move the game from a cooperative equilibrium to a noncooperative equilibrium.

To restore the cooperative equilibrium, the subjects would have to reduce their overharvest from 50 to 12 units each. In this way, the right side of equation (6) would fall from 200 to 48. From equation (5), it follows that the subjects' optimal response would be to overharvest 0 units each in the next round. This combination of events is very unlikely because it requires that all subjects drastically reduce their overharvests by coincidence.

\section{Statistical methods}

Our variable of interest was the mean group overharvest for each different class of group and for each of the 20 rounds of play. We classified the groups in two ways: according to their home community type, i.e., high-performance union, lowperformance union, or nonunionized fishers, and according to their communities' dependency on benthic resources, high, medium, or low.

A comparison of the mean total overharvests of different classes of groups in different rounds is not straightforward. In CPR experiments, actions are highly correlated between subjects and across rounds, because most subjects condition their current actions on the previous actions of their group (Gächter 2007). Therefore, the difference of means tests cannot assume independency between observations.

To account for the correlations between observations, we calculated the mean total overharvests using a fixed-effects regression with cluster-robust standard errors. The regression included fixed-effects for the group classes. The covariance matrix clustered the data by sessions because only the subjects who participated in the same session influenced each other's actions. Formally, the fixed effects regression is as follows:

$$
y_{j t}=\sum_{k \in K} \beta_{k t} D_{j k}+\varepsilon_{j t},
$$

In this equation:

- Index $j$ identifies the group, and index $t$ identifies the round.

- Variable $y_{j t}$ is group $j$ 's overharvest in round $t$, where $y_{j t}$ $\in\{0,1,2, \ldots, 250\}$.

- Variable $D_{j k}$ is a fixed effect that takes value 1 if group $j$ belongs to class $k$; otherwise, it is 0 . Set $K$ is the set of group classes. In the first version of the regression, the classes were high-performance union, low-performance union, and nonunionized fishers. In the second version, 
the classes were high-dependency, medium-dependency, and low-dependency on benthic resources.

- $\varepsilon_{j t}$ is an error term. We assumed $\varepsilon_{j t}$ is normal. This assumption is necessary to compute the cluster-robust standard errors.

Linear regressions, such as the one we used here, assume that dependent variables have an infinite range. Because group overharvest had a limited range ( 0 to 250 units), our linear regression produced approximate confidence intervals. A Tobit regression could help solve this problem. We performed both kinds of regressions, and they produced almost equal results. For ease of exposition, we have chosen to present only the linear regression. The Tobit regression is available upon request.

We carried out additional tests to search for significant differences in overall earnings between the different classes of fishers' unions. First, we performed a Kruskal-Wallis oneway analysis of variance on ranks. To isolate the group or groups that differed from the others, we used Dunns multiple comparison procedure.

All our statistical analyses included all groups originally sampled; no groups were excluded or included after the analyses were made. No observations were dropped in the regressions or hypothesis tests. The complete database is available upon request.

\section{RESULTS}

We present the results of the experiment first in relation to the types of fishing communities and then in relation to their level of dependency on benthic resources. Figure 2 shows the evolution of mean group overharvests for each type of fishing community: high-performance unions, low-performance unions, and nonunionized fishers. Overharvesting produces negative externalities, and hence higher levels of overharvesting correspond to lower levels of cooperation among group members. The following stylized facts about the evolution of cooperation emerged from the experimental results:

1. At the onset of the game, unionized fishers cooperated with each other on the sustainable exploitation of the common pool resource. The members of highperformance unions were the most cooperative subjects, whereas low-performance union members exhibited intermediate levels of cooperation.

2. In the absence of external enforcement, cooperation eroded in the groups of unionized fishers.

3. The enforcement of individual quotas during the regulated regime restored cooperation in the groups of unionized fishers. The members of high-performance unions continued to cooperate until the end of the game.
In contrast, among members of low-performance unions, cooperation eroded once again.

4. Nonunionized fishers never cooperated with each other. Enforcement had no effect on their behavior.

Fig. 2. Evolution of mean group overharvests for each type of fishing community: high-performance unions, lowperformance unions, and nonunionized fishers. The gap in the figure (round 10) represents the implementation of an external sanctioning norm.

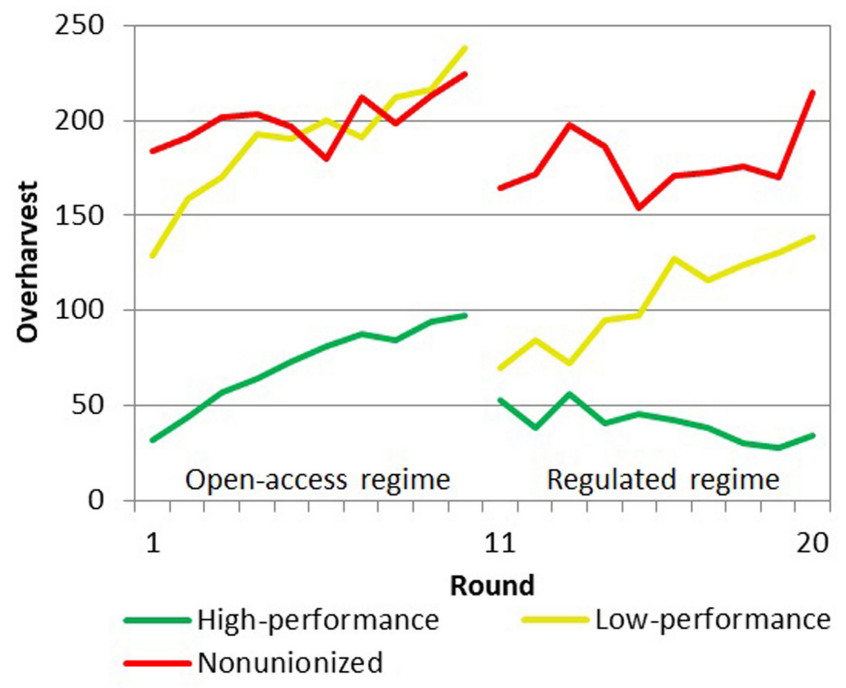

These stylized facts were obtained from the fixed-effects regressions displayed in Table 2. Each coefficient represents the mean total overharvest for a type of group in a particular round. Mean differences tests can be obtained from the results in the table: if the $95 \%$ confidence intervals of two different coefficients did not overlap, the null hypothesis of equal means was rejected with a $95 \%$ confidence level. For greater clarity, the confidence intervals are shown graphically in Figure 3.

The varied levels of cooperation in the separate groups resulted in significant differences in earnings (Kruskal-Wallis one-way test: $\mathrm{H}=40.2, \mathrm{p} \leq 0.001)$. On average, the members of highperformance unions earned CLP\$18,209 (US\$36). Lowperformance union members earned CLP\$12,103 (US\$23), and nonunionized fishers earned CLP\$9021 (US\$18).

Figure 4 graphs the evolution of mean group overharvest amounts for each level of dependency on benthic resources: high, medium, and low dependency. As can be seen in the figure, dependency on benthic resources had no discernible effect on cooperation. Table 3 shows the corresponding fixedeffects regression. The $95 \%$ confidence intervals overlapped 
Table 2. Fixed-effects regression for group overharvest by community type and round of play.

\begin{tabular}{|c|c|c|c|c|c|c|c|}
\hline \multirow{3}{*}{$\begin{array}{l}\text { Linear regression } \\
\text { Overharvest } \\
\text { High-performance unions }\end{array}$} & & \multicolumn{6}{|c|}{ Standard errors adjusted for 17 clusters in sessions } \\
\hline & & \multirow{2}{*}{$\frac{\text { Coefficient }}{32}$} & \multirow{2}{*}{$\frac{\text { Std. Error }}{10}$} & \multirow{2}{*}{$\frac{\text { t-statistic }}{3.31}$} & \multirow{2}{*}{$\frac{\mathrm{p} \text {-value }}{0.00}$} & \multicolumn{2}{|c|}{ [95\% conf. interval] } \\
\hline & Round 1 & & & & & 11 & 52 \\
\hline & 2 & 44 & 15 & 2.96 & 0.01 & 12 & 75 \\
\hline & 3 & 57 & 15 & 3.67 & 0.00 & 24 & 89 \\
\hline & 4 & 64 & 24 & 2.66 & 0.02 & 13 & 115 \\
\hline & 5 & 73 & 28 & 2.62 & 0.02 & 14 & 131 \\
\hline & 6 & 81 & 30 & 2.74 & 0.01 & 18 & 144 \\
\hline & 7 & 88 & 36 & 2.42 & 0.03 & 11 & 164 \\
\hline & 8 & 84 & 24 & 3.50 & 0.00 & 33 & 135 \\
\hline & 9 & 94 & 32 & 2.89 & 0.01 & 25 & 163 \\
\hline & 10 & 97 & 27 & 3.65 & 0.00 & 41 & 153 \\
\hline & 11 & 53 & 25 & 2.11 & 0.05 & 0 & 106 \\
\hline & 12 & 38 & 26 & 1.49 & 0.16 & -16 & 92 \\
\hline & 13 & 56 & 19 & 2.88 & 0.01 & 15 & 97 \\
\hline & 14 & 41 & 20 & 2.01 & 0.06 & -2 & 84 \\
\hline & 15 & 45 & 21 & 2.12 & 0.05 & 0 & 91 \\
\hline & 16 & 42 & 15 & 2.85 & 0.01 & 11 & 74 \\
\hline & 17 & 39 & 25 & 1.53 & 0.15 & -15 & 92 \\
\hline & 18 & 30 & 13 & 2.25 & 0.04 & 2 & 59 \\
\hline & 19 & 27 & 17 & 1.57 & 0.14 & -10 & 64 \\
\hline & 20 & 34 & 16 & 2.08 & 0.05 & -1 & 69 \\
\hline \multirow[t]{20}{*}{ Low-performance unions } & Round 1 & 129 & 25 & 5.12 & 0.00 & 75 & 182 \\
\hline & 2 & 159 & 27 & 5.92 & 0.00 & 102 & 215 \\
\hline & 3 & 170 & 18 & 9.25 & 0.00 & 131 & 209 \\
\hline & 4 & 193 & 12 & 15.78 & 0.00 & 167 & 219 \\
\hline & 5 & 190 & 6 & 32.82 & 0.00 & 178 & 202 \\
\hline & 6 & 200 & 8 & 23.60 & 0.00 & 182 & 218 \\
\hline & 7 & 191 & 14 & 13.76 & 0.00 & 161 & 220 \\
\hline & 8 & 212 & 15 & 14.49 & 0.00 & 181 & 243 \\
\hline & 9 & 217 & 12 & 17.70 & 0.00 & 191 & 243 \\
\hline & 10 & 238 & 5 & 50.71 & 0.00 & 228 & 248 \\
\hline & 11 & 69 & 18 & 3.80 & 0.00 & 31 & 108 \\
\hline & 12 & 84 & 26 & 3.20 & 0.01 & 28 & 140 \\
\hline & 13 & 72 & 28 & 2.62 & 0.02 & 14 & 131 \\
\hline & 14 & 95 & 25 & 3.73 & 0.00 & 41 & 149 \\
\hline & 15 & 97 & 28 & 3.52 & 0.00 & 39 & 156 \\
\hline & 16 & 127 & 17 & 7.46 & 0.00 & 91 & 163 \\
\hline & 17 & 116 & 29 & 3.99 & 0.00 & 54 & 177 \\
\hline & 18 & 124 & 29 & 4.35 & 0.00 & 64 & 185 \\
\hline & 19 & 130 & 18 & 7.18 & 0.00 & 92 & 169 \\
\hline & 20 & 139 & 23 & 5.91 & 0.00 & 89 & 188 \\
\hline \multirow[t]{5}{*}{ Nonunionized fishers } & Round 1 & 184 & 16 & 11.44 & 0.00 & 150 & 218 \\
\hline & 2 & 191 & 14 & 13.67 & 0.00 & 161 & 220 \\
\hline & 3 & 202 & 14 & 14.88 & 0.00 & 173 & 231 \\
\hline & 4 & 203 & 14 & 14.83 & 0.00 & 174 & 232 \\
\hline & 5 & 197 & 18 & 10.71 & 0.00 & 158 & 236 \\
\hline
\end{tabular}




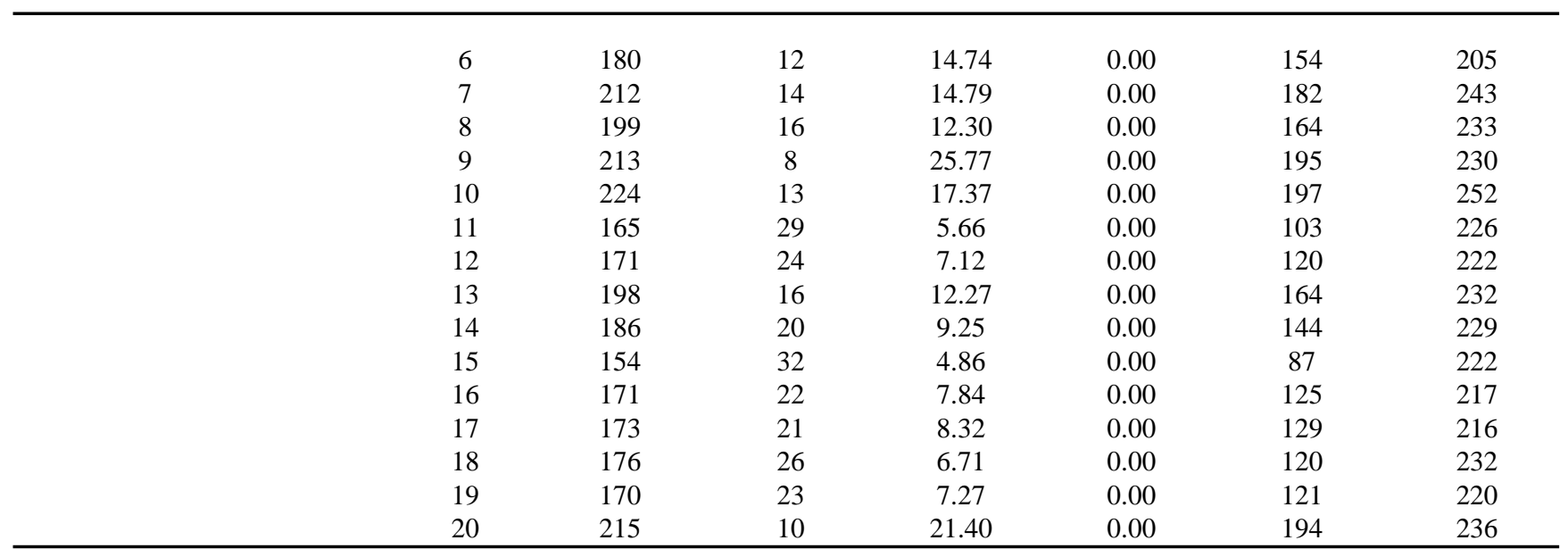

Number of observations: 340

$\mathrm{R}^{2}: 0.69$

throughout the game. No significant differences in earnings were found when the subjects were grouped by their communities' dependency of benthic resources (KruskalWallis one-way test: $\mathrm{H}=2.1, \mathrm{p}=0.35$ ).

Fig. 3. Ninety-five percent confidence intervals for the evolution of mean group overharvests for each type of fishing community: high-performance unions, lowperformance unions, and nonunionized fishers.

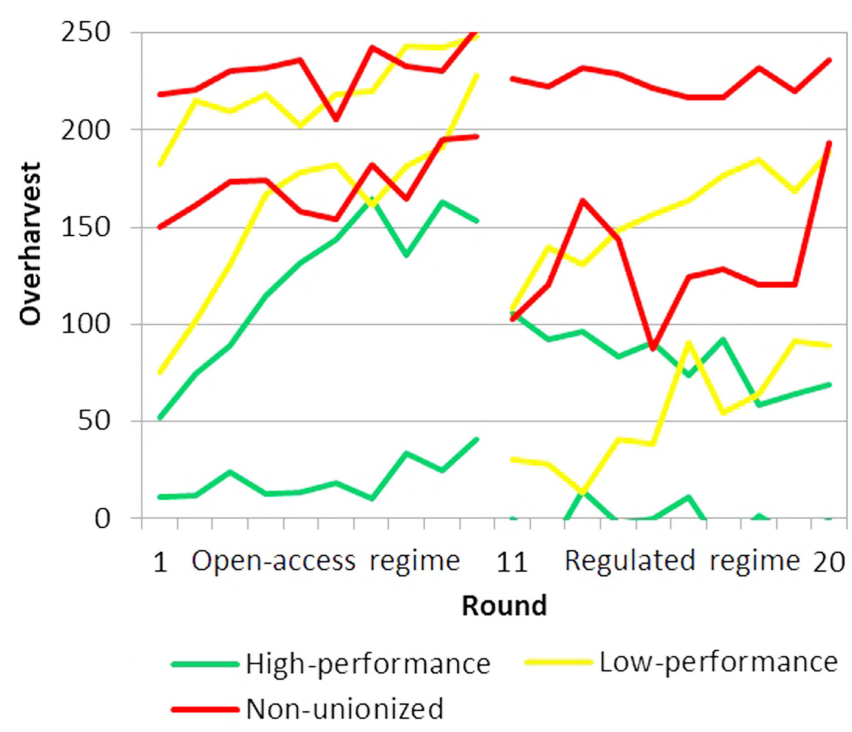

\section{DISCUSSION}

We found experimental evidence that subjects who acted more cooperatively in the experiments came from communities that had good institutions and cooperative practices, measured indirectly as a performance index. This offered evidence of the external validity of the CPR experiment. The results also provided insight about the dynamics of cooperation and its interaction with the imperfect enforcement of a prosocial norm.

Fig. 4. Evolution of mean group overharvests for each level of dependency on benthic resources: high, medium, and low dependency. The gap in the figure (round 10) represents the implementation of an external sanctioning norm.

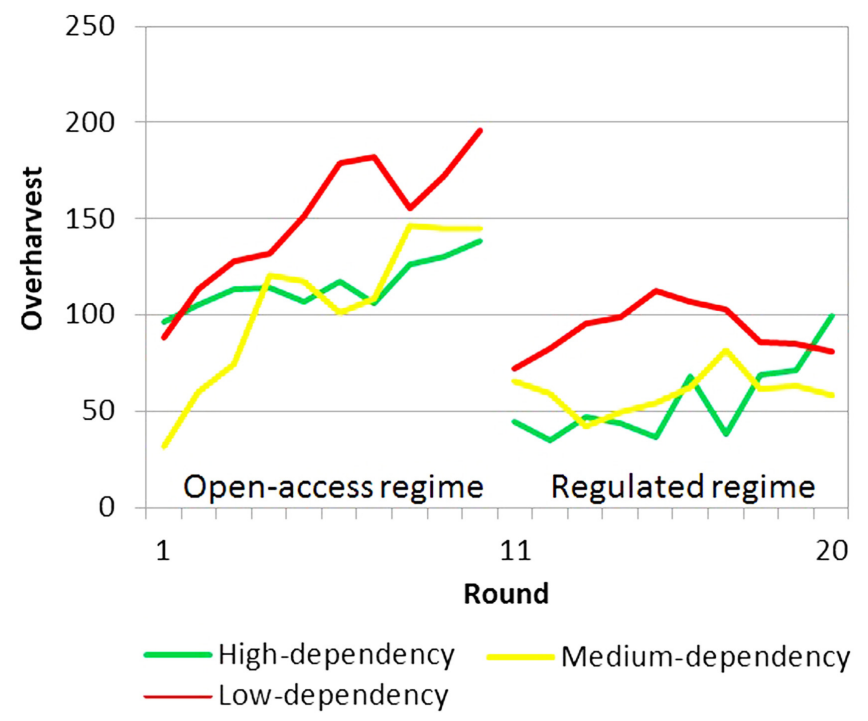

The real-life counterparts of our groups of subjects are fishers' unions with imperfect quota enforcement and nonunionized fishers without quota enforcement. As expected, the introduction of quota enforcement in round 11 coordinated unionized fishers in the cooperative equilibrium. This behavioral change can be explained by a change in 
Table 3. Fixed-effects regression for group overharvest by degree of dependency on benthic resources and round of play.

\begin{tabular}{|c|c|c|c|c|c|c|c|}
\hline \multirow{3}{*}{$\begin{array}{l}\text { Linear regression } \\
\text { Overharvest } \\
\text { High-dependency }\end{array}$} & & \multicolumn{6}{|c|}{ Standard errors adjusted for 11 clusters in sessions } \\
\hline & & \multirow{2}{*}{$\frac{\text { Coefficient }}{96}$} & \multirow{2}{*}{$\begin{array}{c}\text { Std. Error } \\
43\end{array}$} & \multirow{2}{*}{$\frac{\text { t-statistic }}{2.25}$} & \multirow{2}{*}{$\frac{p \text {-value }}{0.05}$} & \multicolumn{2}{|c|}{ [95\% conf. interval] } \\
\hline & Round 1 & & & & & 1 & 191 \\
\hline & 2 & 105 & 50 & 2.10 & 0.06 & -6 & 216 \\
\hline & 3 & 114 & 44 & 2.57 & 0.03 & 15 & 212 \\
\hline & 4 & 115 & 56 & 2.05 & 0.07 & -10 & 239 \\
\hline & 5 & 107 & 49 & 2.18 & 0.05 & -2 & 216 \\
\hline & 6 & 117 & 53 & 2.21 & 0.05 & -1 & 235 \\
\hline & 7 & 106 & 54 & 1.97 & 0.08 & -14 & 226 \\
\hline & 8 & 126 & 58 & 2.16 & 0.06 & -4 & 256 \\
\hline & 9 & 131 & 70 & 1.85 & 0.09 & -26 & 287 \\
\hline & 10 & 138 & 63 & 2.20 & 0.05 & -2 & 278 \\
\hline & 11 & 45 & 14 & 3.20 & 0.01 & 13 & 76 \\
\hline & 12 & 35 & 28 & 1.27 & 0.23 & -27 & 97 \\
\hline & 13 & 47 & 18 & 2.58 & 0.03 & 6 & 87 \\
\hline & 14 & 44 & 29 & 1.50 & 0.17 & -21 & 109 \\
\hline & 15 & 36 & 14 & 2.60 & 0.03 & 5 & 67 \\
\hline & 16 & 69 & 30 & 2.26 & 0.05 & 1 & 136 \\
\hline & 17 & 38 & 25 & 1.51 & 0.16 & -18 & 94 \\
\hline & 18 & 69 & 27 & 2.50 & 0.03 & 8 & 130 \\
\hline & 19 & 71 & 43 & 1.67 & 0.13 & -24 & 166 \\
\hline & 20 & 100 & 49 & 2.06 & 0.07 & -8 & 208 \\
\hline \multirow[t]{20}{*}{ Medium-dependency } & Round 1 & 32 & 17 & 1.94 & 0.08 & -5 & 69 \\
\hline & 2 & 60 & 31 & 1.92 & 0.08 & -10 & 130 \\
\hline & 3 & 75 & 38 & 1.98 & 0.08 & -9 & 159 \\
\hline & 4 & 121 & 63 & 1.91 & 0.09 & -20 & 262 \\
\hline & 5 & 118 & 60 & 1.95 & 0.08 & -17 & 252 \\
\hline & 6 & 101 & 52 & 1.95 & 0.08 & -14 & 217 \\
\hline & 7 & 109 & 56 & 1.96 & 0.08 & -15 & 232 \\
\hline & 8 & 147 & 53 & 2.77 & 0.02 & 29 & 265 \\
\hline & 9 & 145 & 47 & 3.05 & 0.01 & 39 & 250 \\
\hline & 10 & 145 & 53 & 2.75 & 0.02 & 28 & 263 \\
\hline & 11 & 66 & 48 & 1.39 & 0.20 & -40 & 172 \\
\hline & 12 & 59 & 43 & 1.38 & 0.20 & -37 & 155 \\
\hline & 13 & 42 & 28 & 1.49 & 0.17 & -21 & 105 \\
\hline & 14 & 49 & 35 & 1.39 & 0.20 & -30 & 128 \\
\hline & 15 & 55 & 31 & 1.77 & 0.11 & -14 & 124 \\
\hline & 16 & 63 & 31 & 2.00 & 0.07 & -7 & 133 \\
\hline & 17 & 82 & 43 & 1.89 & 0.09 & -14 & 178 \\
\hline & 18 & 61 & 32 & 1.89 & 0.09 & -11 & 134 \\
\hline & 19 & 63 & 35 & 1.82 & 0.10 & -14 & 140 \\
\hline & 20 & 59 & 30 & 1.94 & 0.08 & -9 & 126 \\
\hline \multirow[t]{5}{*}{ Low-dependency } & Round 1 & 88 & 33 & 2.69 & 0.02 & 15 & 161 \\
\hline & 2 & 114 & 41 & 2.75 & 0.02 & 22 & 206 \\
\hline & 3 & 128 & 36 & 3.50 & 0.01 & 46 & 209 \\
\hline & 4 & 132 & 25 & 5.22 & 0.00 & 76 & 188 \\
\hline & 5 & 152 & 28 & 5.49 & 0.00 & 90 & 213 \\
\hline
\end{tabular}




\begin{tabular}{|c|c|c|c|c|c|c|}
\hline 6 & 179 & 24 & 7.36 & 0.00 & 125 & 233 \\
\hline 7 & 182 & 24 & 7.64 & 0.00 & 129 & 235 \\
\hline 8 & 156 & 31 & 5.01 & 0.00 & 86 & 225 \\
\hline 9 & 173 & 18 & 9.38 & 0.00 & 132 & 214 \\
\hline 10 & 196 & 28 & 7.07 & 0.00 & 134 & 258 \\
\hline 11 & 72 & 27 & 2.70 & 0.02 & 13 & 132 \\
\hline 12 & 83 & 36 & 2.30 & 0.04 & 3 & 163 \\
\hline 13 & 95 & 32 & 2.93 & 0.02 & 23 & 168 \\
\hline 14 & 99 & 28 & 3.52 & 0.01 & 36 & 161 \\
\hline 15 & 113 & 37 & 3.01 & 0.01 & 29 & 196 \\
\hline 16 & 107 & 33 & 3.26 & 0.01 & 34 & 180 \\
\hline 17 & 103 & 47 & 2.18 & 0.05 & -2 & 208 \\
\hline 18 & 86 & 53 & 1.63 & 0.14 & -32 & 204 \\
\hline 19 & 86 & 39 & 2.17 & 0.06 & -2 & 173 \\
\hline 20 & 81 & 37 & 2.18 & 0.05 & -2 & 163 \\
\hline
\end{tabular}

Number of observations: 340

$\mathrm{R}^{2}: 0.69$

expectations, which was probably influenced by the subjects' real life experiences (McAdams and Nadler 2005). Given the change in the rules of the game, each subject anticipated that the rest of his group would reduce their overharvests. Therefore, the optimal response of the subject was to reduce his overharvest as well. All subjects reasoned in this way and therefore reduced their overharvests simultaneously, giving rise to a cooperative equilibrium. In simpler terms, the introduction of quota enforcement restored trust and cooperation among the subjects.

However, only the members of high-performance unions were able to take full advantage of the opportunity presented by the new institutional environment, sustaining high levels of cooperation until the end of the game. Because a cooperative equilibrium is unstable, it takes more than a change in expectations to explain why these subjects persisted on cooperating (Rodríguez-Sickert et al. 2008). Possibly, the subjects internalized the prosocial norm, immunizing the cooperative equilibrium against occasional violations by a few members of the group. At first, the groups formed by members of low-performance unions reacted to the threat of confiscation by reducing their overharvest, but they failed to internalize the prosocial norm. Cooperation eroded in these groups. Finally, unmonitored and free from enforcement, nonunionized fishers did not cooperate at all. Their previous negative experiences probably contributed to their uncooperativeness in the experiment (Gunnthorsdottir et al. 2007).

The cooperative inclinations of unionized fishers and their propensity to internalize the prosocial norm have two possible origins; they may precede their experience in comanagement, or they may have been fostered by it. More research is needed to understand the role of comanagement in the internalization of prosocial norms, as opposed to the causal role of stable personality traits on cooperative behavior (Kurzban and
Houser 2001, Gunnthorsdottir et al. 2007, Skatov and Ferguson 2011, Volk et al. 2011, 2012).

When subjects were grouped according to their dependency on benthic resources, no clear differences were observed between the groups. This result was unexpected because other studies have found that dependency correlates with risk preferences and also with attitudes toward comanagement (Gelcich et al. 2007, 2008). Further studies must be performed on this subject.

\section{CONCLUSION}

In our CPR experiment, the subjects' degree of cooperation reflected the cooperativeness of their communities of origin as measured indirectly by the performance index. We find evidence that overall comanagement performance is higher in fisher unions formed by subjects who acted more cooperatively in the experiments. This evidence adds to the findings of two previous experimental studies (Carpenter and Seki 2011, Fehr and Leibbrandt 2011). Carpenter and Seki (2011) studied Japanese artisanal shrimpers. The researchers worked with two different types of shrimper communities. One community pooled their income and operating expenses and the other community did not. They found that poolers cooperated more in the laboratory than nonpoolers. Fehr and Leibbrandt (2011) studied northern Brazilian shrimpers. They reported that the shrimpers who cooperated more in the laboratory used traps with bigger holes. On the other hand, a study by Hill and Gurven (2004) produced no evidence of external validity. The researchers performed a public good experiment (a functional equivalent of the CPR game) with the Aché people of Paraguay. Among the Aché, cooperation in communal projects such as hunting and gathering is an important part of their economic life. However, the subjects' behavior in the experiments was not related to measures of real life cooperativeness, including food-sharing generosity. 
Finally, Gurven and Winking (2008) used a different set of economic games to study the prosocial inclinations of the Tsimané, an indigenous people of Bolivia who fish, hunt, and farm for a living. The researchers reported no correlation between altruism in the economic games and real-life forms of cooperation such as food sharing.

The results of our experiment are in line with previous observations that show that the enforcement of social norms may affect the cooperative inclinations of people (Bowles and Hwang 2008, Bowles and Polania-Reyes 2012). In some contexts, as in our experiment, prosocial norms are internalized by the members of a community, and cooperation among them is reinforced. We hypothesize that the internalization of prosocial norms was a crucial factor to the success of comanagement systems in Chilean benthic fisheries. Further research is needed to gauge the relative importance of norm internalization, self-selection, sanctions, and other incentives in the success of the comanagement systems. The interactions between these factors should also be studied to ensure that the results of these experiments can be safely used as inputs for the design of fishery policies.

Responses to this article can be read online at: http://www.ecologyandsociety.org/issues/responses. $\mathrm{php} / 5598$

\section{Acknowledgments:}

This research was conducted with the financial support of Fondecyt grants \#1120103, \#1110351, and \#1120387, Centro de Conservacion Marina Iniciativa Cientifica Milenio of the Ministerio de Economia, Fomento y Turismo and Anillo CONICYT SOC1101. We thank the fishing communities who kindly volunteered to participate in the field experiments and the presidents of the fishers' unions who provided logistical support. Special thanks are also given to Rodrigo Troncoso for valuable comments and discussion. In addition, $M$. Bennett, N. Godoy, F. Godoy, M. Santis, and V. Ortiz provided outstanding research assistance. The study complies with the Pontificia Universidad Catolica and Fondecyt ethical requirements.

\section{LITERATURE CITED}

Bardsley, N., R. Cubbit, G. Loomes, P. Moffatt, C. Starmer, and R. Sugden. 2010. Experimental economics: rethinking the rules. Princeton University Press, Princeton, New Jersey, USA.

Bowles, S., and S. H. Hwang. 2008. Social preferences and public economics: mechanism design when social preferences depend on incentives. Journal of Public Economics 92:1811-1820. http://dx.doi.org/10.1016/j.jpubeco.2008.03.006

Bowles, S., and S. Polania-Reyes. 2012. Economic incentives and social preferences: substitutes or complements? Journal of Economic Literature 50:368-425. http://dx.doi.org/10.1257/ jel.50.2.368

Cárdenas, J. C. 2003. Real wealth and experimental cooperation: evidence in the field lab. Journal of Development Economics 70:263-289. http://dx.doi.org/10.1016/S0304-3878 (02)00098-6

Cárdenas, J. C. 2004. Norms from outside and from inside: an experimental analysis on the governance of local ecosystems. Forest Policy and Economics 6:229-241. http://dx.doi. org/10.1016/j.forpol.2004.03.006

Cárdenas, J. C. 2009. Experiments in environment and development. Annual Review of Resource Economics 1:157-182. http://dx.doi.org/10.1146/annurev.resource.050708.144056

Cárdenas, J. C. 2011. Social norms and behavior in the local commons as seen through the lens of field experiments. Environmental and Resource Economics 48:451-485. http:// dx.doi.org/10.1007/s10640-010-9452-8

Cárdenas, J. C., and E. Ostrom. 2004. What do people bring into the game? Experiments in the field about cooperation in the commons. Agricultural Systems 82:307-326. http://dx.doi. org/10.1016/j.agsy.2004.07.008

Carpenter J., and E. Seki. 2011. Do social preferences increase productivity? Field experimental evidence from fishermen in Toyama bay. Economic Inquiry 49:612-630. http://dx.doi. org/10.1111/j.1465-7295.2009.00268.x

Castilla, J. C. 2010. Fisheries in Chile: small-pelagics, management, rights and sea zoning. Bulletin of Marine Science $86: 221-234$.

Castilla, J. C., and S. Gelcich. 2008. Management of the loco (Concholepas concholepas) as a driver for self-governance of small-scale benthic fisheries in Chile. Pages 441-451 in R. E. Townsend, R. Shotton, and H. Uchida, editors. Case studies in fisheries self-governance. Food and Agriculture Organisation of the United Nations, Rome, Italy.

Cinner, J. E., T. R. McClanahan, M. A. MacNeil, N. A. J. Graham, T. M. Daw, A. Mukminin, D. A. Feary, A. L. Rabearisoa, A. Wamukota, N. Jiddawik, S. J. Campbell, A. H. Baird, F. A. Januchowski-Hartley, S. Hamed, R. Lahari, T. Morove, and J. Kuange. 2012. Comanagement of coral reef social-ecological systems. Proceedings of the National Academy of Sciences 109:5219-5222. http://dx.doi. org/10.1073/pnas.1121215109 
Fanning, L. M. 2000. The comanagement paradigm: examining criteria for meaningful public involvement in sustainable marine resource management. Pages 80-113 in E. Mann, A. Chircop, M. McConnell, and J. Morgan, editors. Ocean Yearbook 14. University of Chicago Press, Chicago, Illinois, USA. http://dx.doi.org/10.1163/221160000X00080

Fehr, E., and A. Leibbrandt. 2011. A field study on cooperativeness and impatience in the tragedy of the commons. Journal of Public Economics 95:1144-1155. http:// dx.doi.org/10.1016/j.jpubeco.2011.05.013

Fischbacher, U. 2007. z-Tree: Zurich toolbox for ready-made economic experiments. Experimental Economics 10:171-178. http://dx.doi.org/10.1007/s10683-006-9159-4

Gächter, S. 2007. Conditional cooperation: behavioral regularities from the lab and the field and their policy implications. Pages 19-50 in B. Frey and A. Stutzer, editors. Economics and psychology: a promising new crossdisciplinary field. CESifo Seminar Series. MIT Press, Cambridge, Massachusetts, USA.

Gelcich, S., G. Edwards-Jones, and M. J. Kaiser. $2005 b$. Importance of attitudinal differences among artisanal fishers toward co-management and conservation of marine resources. Conservation Biology 19:865-875. http://dx.doi.org/10.1111/ j.1523-1739.2005.00534.x

Gelcich, S., G. Edwards-Jones, and M. J. Kaiser. 2007. Heterogeneity in fishers' harvesting decisions under a marine territorial user rights policy. Ecological Economics 61:246-254. http://dx.doi.org/10.1016/j.ecolecon.2006.02.017

Gelcich, S, G. Edwards-Jones, M. J. Kaiser, and J. C. Castilla. 2006. Co-management policy can reduce resilience in traditionally managed marine ecosystems. Ecosystems 9:951-966. http://dx.doi.org/10.1007/s10021-005-0007-8

Gelcich, S., G. Edwards-Jones, M. J. Kaiser, and E. Watson. 2005a. Using discourses for policy evaluation: the case of marine common property rights in Chile. Society \& Natural Resources 18:377-391. http://dx.doi.org/10.1080/08941920590915279

Gelcich, S., N. Godoy, and J. C. Castilla. 2009. Artisanal fishers' perceptions regarding coastal co-management policies in Chile and their potentials to scale-up marine biodiversity conservation. Ocean \& Coastal Management 52:424-432. http://dx.doi.org/10.1016/j.ocecoaman.2009.07.005

Gelcich, S., T. P. Hughes, P. Olsson, C. Folke, O. Defeo, M. Fernández, S. Foale, L. H. Gunderson, C. Rodríguez-Sickert, M. Scheffer, R. S. Steneck, and J. C. Castilla. 2010. Navigating transformations in governance of Chilean marine coastal resources. Proceedings of the National Academy of Sciences 107:16794-16799. http://dx.doi.org/10.1073/pnas.1012021107

Gelcich, S., M. J. Kaiser, J. C. Castilla, and G. Edwards-Jones. 2008. Engagement in co-management of marine benthic resources influences environmental perceptions of artisanal fishers. Environmental Conservation 35:36-45. http://dx.doi. org/10.1017/S0376892908004475

George, A. L. 2005. Case studies and theory development in the social sciences. MIT Press, Cambridge, Massachusetts, USA.

Gunnthorsdottir, A., D. Houser, and K. McCabe. 2007. Disposition, history and contributions in public goods experiments. Journal of Economic Behavior \& Organization 62:304-315. http://dx.doi.org/10.1016/j.jebo.2005.03.008

Gurven, M., and J. Winking. 2008. Collective action in action: prosocial behavior in and out of the laboratory. American Anthropologist 110:179-190. http://dx.doi.org/10.1111/ j.1548-1433.2008.00024.x

Hardin, G. 1968. The tragedy of the commons. Science 162:1243-1248. http://dx.doi.org/10.1126/science.162.3859.1243

Hill, K., and M. Gurven. 2004. Economic experiments to examine fairness and cooperation among the Ache Indians of Paraguay. Pages 382-412 in J. Henrich, R. Boyd, S. Bowles, C. Camerer, E. Fehr, and H. Gintis, editors. Foundations of human sociality: economic experiments and ethnographic evidence from fifteen small-scale societies. Oxford University Press, Oxford, UK. http://dx.doi.org/10.1093/0199262055.003.0013

Kurzban, R., and D. Houser. 2001. Individual differences in cooperation in a circular public goods game. European Journal of Personality 15:S37-S52. http://dx.doi.org/10.1002/ per. 420

Levitt, S. D., and J. A. List. 2007. What do laboratory experiments measuring social preferences reveal about the real world? Journal of Economic Perspectives 21:153-174. http:// dx.doi.org/10.1257/jep.21.2.153

Marín, A., S. Gelcich, J. C. Castilla, and F. Berkes. 2012. Exploring social capital in Chile's coastal benthic comanagement system using a network approach. Ecology and Society 17(1): 13. http://dx.doi.org/10.5751/ES-04562-170113

McAdams, R. H., and J. Nadler. 2005. Testing the focal point theory of legal compliance: the effect of third party expression in an experimental hawk/dove game. Journal of Empirical Legal Studies 2(1):87-123. http://dx.doi.org/10.1111/ j.1740-1461.2005.00032.x

Meltzoff, S. K., Y. G. Lichtensztajn, and W. Stotz. 2002. Competing visions for marine tenure and co-management: genesis of a marine management area system in Chile. Coastal Management 30:85-99. http://dx.doi.org/10.1080/08920750$\underline{252692634}$

Nielsen, J. R., P. Degnbol, K. Viswanathan, M. Ahmed, M. Hara, and N. M. R. Abdullah. 2004. Fisheries co-management: an institutional innovation? Lessons from South East Asia and 
Southern Africa. Marine Policy 28:151-160. http://dx.doi. org/10.1016/S0308-597X(03)00083-6

Ostrom, E. 1990. Governing the commons: the evolution of institutions for collective action. Cambridge University Press, Cambridge, UK. http://dx.doi.org/10.1017/CBO9780511807763

Ostrom, E. 2006. The value-added of laboratory experiments for the study of institutions and common-pool resources. Journal of Economic Behavior \& Organization 61:149-163. http://dx.doi.org/10.1016/j.jebo.2005.02.008

Ostrom, E., J. Walker, and R. Gardner. 1992. Covenants with and without a sword: self-governance is possible. American Political Science Review 86:404-417. http://dx.doi. org/10.2307/1964229

Pomeroy, R. S., and F. Berkes. 1997. Two to tango: the role of government in fisheries co-management. Marine Policy 21:465-480. http://dx.doi.org/10.1016/S0308-597X(97)00017-1

Rodríguez-Sickert, C., R. A .Guzmán, and J. C. Cárdenas. 2008. Institutions influence preferences: evidence from a common pool resource experiment. Journal of Economic Behavior \& Organization 67:215-227. http://dx.doi. org/10.1016/j.jebo.2007.06.004

Schurman, R. A. 1996. Snails, southern hake and sustainability: neoliberalism and natural resource exports in Chile. World Development 24:1695-1709. http://dx.doi. org/10.1016/0305-750X(96)00069-1

Sen, S., and J. R. Nielsen. 1996. Fisheries co-management: a comparative analysis. Marine Policy 20:405-418. http://dx. doi.org/10.1016/0308-597X(96)00028-0

Servicio Nacional de Pesca y Acuicultura (Sernapesca). 2012. Estadisticas de Desembarques. Government of Chile, Valparaíso, Chile. [online] URL: http://www.sernapesca.cl/ index.php?option $=$ com remository \&Itemid $=54 \&$ func $=$ select $\& i d=2$

Singh, K. 1994. Managing common pool resources: principles and case studies. Oxford University Press, New Delhi, India.

Skatov, A., and E. Ferguson. 2011. What makes people cooperate? Individual differences in BAS/BIS predict strategic reciprocation in a public goods game. Personality and Individual Differences 51:237-241. http://dx.doi. org/10.1016/j.paid.2010.05.013

Subsecretaría de Pesca (SUBPESCA). 2010. Estado Actual de las Areas de Manejo. Subsecretaría de Pesca y Acuicultura, Valparaíso, Chile.

Thorpe, J., A. Ibarra, and C. Reid. 1999. The new economic model and fisheries development in Latin America. Centre for the Economics and Management of Aquatic Resources Research Paper 141. Department of Economics, University of Portsmouth, Portsmouth, UK.
Volk, S., C. Thöni, and W. Ruigrok. 2011. Personality, personal values and cooperation preferences in public goods games: a longitudinal study. Personality and Individual Differences 50:810-815. http://dx.doi.org/10.1016/j.paid.2011.01.001

Volk, S., C. Thöni, and W. Ruigrok. 2012. Temporal stability and psychological foundations of cooperation preferences. Journal of Economic Behavior and Organization 81:664-676. http://dx.doi.org/10.1016/j.jebo.2011.10.006

Erratum: The original publication included errors in the translation of the abstract. The errors were corrected on 31 July 2013. 


\section{Appendix 1. The comanagement performance index}

The following table describes the seven variables that composed the co-management performance index. All these variables are closely related to cooperation among members of a fishers' union. The index ranges from 0 to 1 . It corresponds to the simple average of the seven variables.

\begin{tabular}{|c|c|c|c|c|c|}
\hline $\begin{array}{l}\text { Performance } \\
\text { domain }\end{array}$ & Variable & $\begin{array}{l}\text { Survey question or } \\
\text { statistical indicator }\end{array}$ & Scale & $\begin{array}{l}\text { Justification for } \\
\text { inclusion }\end{array}$ & Source \\
\hline \multirow[t]{2}{*}{$\begin{array}{l}\text { Internal } \\
\text { enforcement and } \\
\text { compliance with the } \\
\text { union norms, as } \\
\text { assessed by the } \\
\text { president of the } \\
\text { union. }\end{array}$} & $\begin{array}{l}\text { Internal } \\
\text { enforcement of the } \\
\text { union norms. }\end{array}$ & $\begin{array}{l}\text { Is there internal } \\
\text { enforcement of the } \\
\text { union norms? }\end{array}$ & $\begin{array}{l}1=24 \text { hour a day } \\
\text { enforcement; } \\
0.66=\text { Day or night } \\
\text { enforcement; } \\
0.33 \text { = Enforcement } \\
\text { only in good sea } \\
\text { conditions; } \\
0=\text { No } \\
\text { enforcement. } \\
\end{array}$ & $\begin{array}{l}\text { Enforcement } \\
\text { incentivizes } \\
\text { compliance with } \\
\text { norms, including } \\
\text { those that deal with } \\
\text { cooperative } \\
\text { behaviors. }\end{array}$ & $\begin{array}{l}\text { Adapted from } \\
\text { Gelcich et al. (2009). }\end{array}$ \\
\hline & $\begin{array}{l}\text { Compliance with the } \\
\text { union norms. }\end{array}$ & $\begin{array}{l}\text { Do the union } \\
\text { members comply } \\
\text { with the norms? }\end{array}$ & $\begin{array}{l}5 \text { point Likert scale: } \\
\text { Highly agree }=1 ; \\
\text { Highly disagree }=0 .\end{array}$ & \begin{tabular}{|l|} 
Many norms \\
mandate cooperative \\
behaviors, such as \\
not overharvesting. \\
\end{tabular} & $\begin{array}{l}\text { Adapted from Marin } \\
\text { et al. (2012) and } \\
\text { Gelcich (2009). }\end{array}$ \\
\hline \multirow[t]{3}{*}{$\begin{array}{l}\text { Co-management } \\
\text { performance as } \\
\text { assessed by the } \\
\text { National Fisheries } \\
\text { Service. }\end{array}$} & $\begin{array}{l}\text { Compliance with the } \\
\text { MEABR norms. }\end{array}$ & $\begin{array}{l}\text { How closely does } \\
\text { the union follow the } \\
\text { rules and procedures } \\
\text { to exploit and } \\
\text { maintain its } \\
\text { MEABR? }\end{array}$ & $\begin{array}{l}5 \text { point Likert scale: } \\
1=\text { To the letter; } \\
0=\text { Not at all. }\end{array}$ & $\begin{array}{l}\text { Compliance is } \\
\text { largely a result of } \\
\text { cooperation between } \\
\text { union members. }\end{array}$ & $\begin{array}{l}\text { Adapted from Marin } \\
\text { et al. (2012). }\end{array}$ \\
\hline & $\begin{array}{l}\text { Quality of the } \\
\text { institutions and } \\
\text { social practices. }\end{array}$ & $\begin{array}{l}\text { Is the union a model } \\
\text { case of co- } \\
\text { management? }\end{array}$ & $\begin{array}{l}1=\text { Yes } \\
0=\text { No }\end{array}$ & $\begin{array}{l}\text { Better institutions } \\
\text { and practices } \\
\text { promote } \\
\text { cooperation. }\end{array}$ & $\begin{array}{l}\text { Adapted from Main } \\
\text { et al. (2012); } \\
\text { Unpublished survey }\end{array}$ \\
\hline & $\begin{array}{l}\text { Overall performance } \\
\text { in the co- } \\
\text { management of the } \\
\text { MEABR. }\end{array}$ & $\begin{array}{l}\text { Which of these } \\
\text { words best describes } \\
\text { the overall } \\
\text { performance of the } \\
\text { MEABR? }\end{array}$ & $\begin{array}{l}1=\text { Success } \\
0.75=\text { Stability; } \\
0.5=\text { Improvement; } \\
0.25=\text { Stagnation; } \\
0=\text { Failure }\end{array}$ & $\begin{array}{l}\text { Performance } \\
\text { depends largely on } \\
\text { the cooperation } \\
\text { between union } \\
\text { members } \\
\end{array}$ & $\begin{array}{l}\text { Adapted from Marin } \\
\text { et al (2012). } \\
\text { Unpublished survey }\end{array}$ \\
\hline \multirow[t]{2}{*}{$\begin{array}{l}\text { Ecological } \\
\text { performance. }\end{array}$} & $\begin{array}{l}\text { Trend in the annual } \\
\text { TAC. }\end{array}$ & Official annual TAC. & $\begin{array}{l}1=\text { Increased } \\
0=\text { Decreased } \\
0.5=\text { Maintained }\end{array}$ & $\begin{array}{l}\text { TAC falls if the } \\
\text { community } \\
\text { overexploits the } \\
\text { resource. }\end{array}$ & SUBPESCA 2012. \\
\hline & $\begin{array}{l}\text { Biodiversity } \\
\text { response as } \\
\text { compared to } \\
\text { adjacent open-access } \\
\text { areas. }\end{array}$ & $\begin{array}{l}\text { Biodiversity } \\
\text { measured as overall } \\
\text { species richness }\end{array}$ & $\begin{array}{l}\text { Log response ratios } \\
\text { between adjacent } \\
\text { open access areas } \\
\text { and MEABR. } \\
0=0 \\
>0.1=1\end{array}$ & $\begin{array}{l}\text { Preservation of } \\
\text { biodiversity is a } \\
\text { cooperative } \\
\text { endeavor. }\end{array}$ & $\begin{array}{l}\text { Gelcich et al. (2012), } \\
\text { and Centre for } \\
\text { Marine } \\
\text { Conservation } \\
\text { surveys (available } \\
\text { from the authors). }\end{array}$ \\
\hline
\end{tabular}




\section{Appendix 2. Instructions of the experiment}

The experiment's instructions were originally written in Spanish, the language spoken in Chile. A monitor read the instructions aloud to the subjects at the beginning of each session. The subjects were allowed to interrupt the reading at any time to ask questions. Here, we present an English translation of the instructions. The text in parentheses describes actions performed by the monitor or by the subjects.

(Five subjects enter the room and sit in front of the computers. They are greeted by the monitor.)

"Welcome, and thank you for being here. You are about to participate in an experiment. You have been randomly chosen from the list of union members provided by the union president. This experiment is part of a research project carried out by Pontificia Universidad Católica about the co-management of benthic resources. This project is not related whatsoever to the Undersecretary of Fisheries or the National Fisheries Service.

"We will spend about an hour playing a game. By participating in the game, you will earn between 10 and 20 thousand pesos. You will be paid privately at the end of the game.

"I will read the instructions now. If you have any questions, please raise your hand, and I will answer. Let's begin.

"First, the game is played using computers. Don't worry if you have never used a computer before. You will only have to use the number keys like on a calculator or phone.

"The game recreates a situation where you go fishing for loco, and you must decide how many loco to harvest. The game is divided into 20 rounds. You are assigned an individual quota of 100 loco per round. The computer will assume that you always harvest the whole quota, but you can overharvest up to 50 extra loco per round. Overharvesting benefits you but harms the other members of your group. For every loco you overharvest, the others lose half a loco each. Similarly, for every 2 loco you overharvest, the others lose 1 each.

"In each round, the computer will ask you the same question: "How many extra loco do you want to overharvest?" (from 0 to 50). If you want to comply with your individual quota, your answer should be 0 . You must answer using the number keys, and then press Enter (Monitor shows fishers on the computer). Your answers will be stored anonymously in the computer. The researchers and the other players will never know how many loco you overharvested. Your identity will be hidden from them and us. To maintain anonymity, it is very important that you remain silent during the game. Talking is forbidden.

"I will now show you the screens that you will see on your computer while playing the game."

(The monitor projects the user interface onto the wall.)

"In each round, the following screen will appear. You must decide how many units to overharvest. Please enter your decision inside this box, and then press Enter. Remember, you can 
overharvest between 0 and 50 units per round. Once you and the other four players have entered your decisions, the following screen will appear."

(The monitor shows the next screen.)

"This screen summarizes the results of the round. As you can see, the first box shows your harvest, and the second box shows your group's average harvest. The third box shows how many loco you lost due to the other fishers' overharvest, and the fourth box shows the amount of money that will be added to your account. Remember that your gains will accumulate during the game. Once you see your results for the round, you can press any button, and a new round will begin.

"Now you will play five rounds for practice that will not count towards your earnings. Please raise your hand if you have any difficulties using the computer or don't understand what boxes mean. I will immediately answer any questions. Remember that talking is not allowed."

(The subjects play the five rounds of practice.)

"The trial rounds have finished. Now, the actual game will start. From now on, you will be playing for real money. Good luck."

(After round 10, a screen appears on the computers, which the monitor reads aloud.)

"From now on, the rules of the game will change. The computer will play the role of the National Fisheries Service. After each of the remaining rounds, the computer will inspect two subjects selected at random. If the computer finds that a subject has exceeded his quota, it will confiscate the subject's entire harvest of that round. You will know if you were inspected because a message will appear on your screen. You will not know who of the other members was inspected, or whether or not he was sanctioned."

(At the end of the game, an assistant leads the subjects out of the room. He gives them a brief survey, and then pays them in sealed envelopes. In parallel, the monitor leads the next group in. There is no communication between groups.) 